\title{
Retention time of chromium-labelled feed particles and of water in the gut of sheep given hay and concentrate at maintenance
}

\author{
BY J. E. LINDBERG \\ Department of Animal Nutrition and Management, Swedish University of Agricultural \\ Sciences, S-750 07 Uppsala, Sweden
}

(Received 12 April 1984 - Accepted 26 November 1984)

\begin{abstract}
1. Sheep were given a diet of $400 \mathrm{~g}$ chopped grass hay $/ \mathrm{d}$ and $500 \mathrm{~g}$ crushed barley $/ \mathrm{d}$ in three equal meals. The mean retention time in the whole gut (MRT) and the rumen retention time (RRT) of chromium-labelled feed particles and of water were estimated from marker concentrations in faecal samples.

2. MRT of $\mathrm{Cr}$-labelled hay $(\mathrm{Cr}-\mathrm{H})$, barley hulls $(\mathrm{Cr}-\mathrm{Bh})$, crushed peas (Pisum sativum) (Cr-CP) and rapeseed meal (Cr-RSM) were $53 \cdot 5,52 \cdot 3,44 \cdot 3$ and $37.0 \mathrm{~h}$ respectively when estimated from total faecal collections. The estimates obtained from spot samples of faeces were almost identical.

3. RRT of Cr-H, Cr-Bh, Cr-CP, Cr-RSM (Expts 1, 2 and 3) and Cr-labelled cottonseed meal (Cr-CSM) was $35 \cdot 9,36 \cdot 7,25 \cdot 3,18 \cdot 8,19 \cdot 8,22 \cdot 8$ and $25 \cdot 3 \mathrm{~h}$ respectively.

4. The Cr-labelled feed particles showed marked variations in density in water $\left(D_{w}\right)$. However, both MRT and RRT were closely related to $D_{w}(r-0.88$ and -0.95 respectively).

5. Rumen outflow rates of Cr-RSM in individual animals were related to the rumen outflow rates of water $(r \quad 0 \cdot 76)$.
\end{abstract}

Knowledge of the partition of digestion within the gastrointestinal (GI) tract is essential for the understanding of the amounts and proportions of nutrients absorbed. The rumen has a major influence on the digestion of both energy and protein in ruminants which is well recognized in recent protein evaluation systems (Institut National de la Recherche Agronomique, 1978; Agricultural Research Council, 1980).

In order to make predictions of the quantitative importance of rumen digestion on fibre and protein (Waldo et al. 1973; Ørskov \& McDonald, 1979), information is needed on the rate of outflow of feed particles from the rumen. However, much of the existing information only refers to mean retention time in the whole GI tract (Warner, 1981).

The markers used to study particle flow have been either stained feed particles (Balch, 1950 ) or different rare-earth metals (Ellis \& Huston, 1968) adhering to the feed particles. The main disadvantage with existing particle markers is the migration of label between particles during digestion (Ellis \& Huston, 1968; Faichney \& Griffiths, 1978; Hartnell \& Satter, 1979; Dixon et al. 1983). The introduction of an alternative technique for specific labelling of the feed particles with chromium (Udén $e t$ al. 1980) allows estimates of retention time to be made while avoiding the previously mentioned disadvantage.

The objective of the following experiments was to study the rate of passage of different Cr-labelled feed particles and of water from the rumen and through the entire GI tract of sheep.

MATERIAL AND METHODS

Animals

A total of six castrated Swedish Landrace sheep were used. They were about 3 years old and weighed on average $55 \mathrm{~kg}$ live weight. 
Diets

In all experimental periods the sheep were given daily $400 \mathrm{~g}$ chopped grass hay ( $13.9 \mathrm{~g}$ crude protein $(\mathrm{CP}$, nitrogen $\times 6.25)$ and $639 \mathrm{~g}$ neutral detergent fibre (NDF)/ $\mathrm{kg}$ dry matter (DM)) and $500 \mathrm{~g}$ crushed barley ( $131 \mathrm{~g} \mathrm{CP}$ and $16.4 \mathrm{~g} \mathrm{NDF} / \mathrm{kg} \mathrm{DM}$ ) in three equal meals at 07.00 , 14.30 and 23.00 hours.

\section{Retention-time measurements}

The retention time of feed particles (hay $(\mathrm{Cr}-\mathrm{H})$, barley hulls $(\mathrm{Cr}-\mathrm{Bh})$, rapeseed meal (Cr-RSM), cottonseed meal (Cr-CSM), crushed peas (Pisum sativum) (Cr-CP)) was estimated with $\mathrm{Cr}$-labelled feeds. The feeds were treated with sodium dichromate according to the method described by Uden et al. (1980) for treatment of plant fibres. Barley hulls were obtained by pretreating crushed barley with amylase (EC 3.2.1.1 and 3.2.1.2).

The retention time of water was measured with Li-CoEDTA (Udén et al. 1980).

\section{Particle-size determination}

Dry sieving was performed using a Buhler sieve shaker. Samples $(50 \mathrm{~g})$ were shaken for $5 \mathrm{~min}$ using sieves with openings ranging from 219 to $1610 \mu \mathrm{m}(219,460,670,1110,1610 \mu \mathrm{m})$.

For all samples sieved (hay was not sieved), mean particle size (MPS) was calculated using the following formula:

$$
\text { MPS }=\frac{\Sigma(x, y)_{i}}{\Sigma y_{i}}
$$

where $y_{i}$ is the amount passing screen $i$ but not screen $i+1$ and $x_{i}$ is the size opening of screen $i$ (Udén \& Van Soest, 1982).

\section{Density measurement}

The density $\left(D_{w}\right)$ was estimated using volumetric flasks $(50 \mathrm{ml})$ and water with sodium nitrite $(0 \cdot 2 \mathrm{~g} / 1)$ added to avoid microbial activity. Cr-treated hay $(\mathrm{Cr}-\mathrm{H})$ was milled to pass a $4.5 \mathrm{~mm}$ screen before analysis. The other samples were not milled before analysis. A dry sample $(5-10 \mathrm{~g})$ was weighed into a volumetric flask $(50 \mathrm{ml})$ and water added to soak the sample. The flask was left overnight (12-14 h), shaken twice the following day to remove trapped air and the water volume adjusted. It was then left for a second night and shaken once after which water volume was adjusted and the weight measured.

\section{Experimental design}

Expt 1 was designed to compare the rumen outflow rates of large and small feed particles. Four sheep were allocated to $\mathrm{Cr}-\mathrm{H}, \mathrm{Cr}-\mathrm{BH}, \mathrm{Cr}-\mathrm{RSM}$ and $\mathrm{Cr}-\mathrm{CP}$ according to a Latin-square design. A single dose of Cr-labelled feed $(20 \mathrm{~g})$ was mixed with a portion of the diet. Total faecal samples were collected $8 \mathrm{~h}$ after dosage and every $4 \mathrm{~h}$ over $4 \mathrm{~d}$. Due to loose faeces one sheep was taken out of the experiment after two periods.

The objective of Expt 2 was to see if the addition of unlabelled small feed particles (rapeseed meal) had any influence on the rumen outflow rates of Cr-RSM and water. Four sheep were allocated to four treatments according to a Latin-square design. In treatment $1,20 \mathrm{~g} \mathrm{Cr}-\mathrm{RSM}$ and $2.0 \mathrm{~g} \mathrm{Li-CoEDTA}$ were mixed with a portion of the diet. The treatments 2, 3 and 4 consisted of an additional 20,40 and $80 \mathrm{~g}$ unlabelled RSM respectively. Total faecal samples were collected $24 \mathrm{~h}$ after dosage, every $4 \mathrm{~h}$ on the $2 \mathrm{nd}$ day and every $8 \mathrm{~h}$ for $3 \mathrm{~d}$.

Due to the limited number of observations on rumen outflow rates of small feed particles (Cr-RSM) and water obtained in Expt 2, it was decided to collect additional information in order to allow a comparison of rumen outflow of Cr-RSM and water. Therefore, in Expt 3, four sheep were allocated to Cr-RSM $(20 \mathrm{~g})$ and Li-CoEDTA $(2 \cdot 0 \mathrm{~g})$ for three 
separate periods and Cr-CSM (20 g) and Li-CoEDTA $(2.0 \mathrm{~g})$ for one period. The allocation was not made at random. Spot samples of faeces were collected at the same time intervals as described in Expt 2. The values from one sheep on Cr-RSM during period 3 was excluded due to loose faeces.

In all experiments a new collection period was started at the earliest every 7 th day.

\section{Sample preparation and chemical analysis}

The faecal samples were dried at $65^{\circ}$. Faecal samples from Expt 1 were ashed and the ash digested with a sulphuric acid - phosphoric acid mixture (Stevenson \& de Langen, 1960). The dry faecal samples from Expts 2 and 3 were digested at $100^{\circ}$ with $100 \mathrm{ml} 2 \mathrm{M}-\mathrm{H}_{2} \mathrm{SO}_{4}$ for $1 \mathrm{~h}$, diluted to $200 \mathrm{ml}$ and filtered.

$\mathrm{Cr}$ and cobalt were determined by atomic absorption spectrophotometry.

Total $\mathrm{N}$ in feeds was analysed according to the conventional Kjeldahl procedure and neutral detergent fibre according to Van Soest \& Wine (1967) and Robertson \& Van Soest (1977) in hay and barley respectively.

\section{Calculations}

Fractional outflow rates from the rumen were estimated from the decline in marker concentrations in the faeces (Grovum \& Williams, 1973; Elimam \& Orskov, 1981) according to the function:

$$
C=C_{0} e^{-k t}
$$

where $C$ is the concentration of $\mathrm{Cr}$ or $\mathrm{Co}$ in faeces at time $t, C_{0}$ is the concentration of $\mathrm{Cr}$ or Co in faeces at time $t_{0}, k$ is the flow rate constant and $t$ is the time (h).

The start of the decline in the excretion curve was estimated by eye. Rumen retention time (RRT) was calculated as $1 / k$ (Shipley \& Clark, 1972) assuming one-compartment kinetics.

Mean retention time (MRT) in the whole GI tract was estimated according to Thielemans et al. (1978) by:

$$
\mathrm{MRT}_{\mathrm{T}}=\frac{\sum_{i=1}^{n} t_{i} C_{i} \Delta t_{i}}{\sum_{i=1}^{n} C_{i} \Delta t_{i}}
$$

where $t_{i}$ is the time (h) elapsed since dosage of marker to the mid-point in the $i$ th collection interval, $C_{i}$ is the concentration of marker in the $i$ th sample, $\Delta t_{i}$ is the faecal collection interval (h) and $n$ is the number of faecal samples; and according to Blaxter et al. (1956) by:

$$
\mathrm{MRT}_{\mathrm{B}}=\frac{\sum_{i=1}^{n} m_{i} t_{i}}{\sum_{i=1}^{n} m_{i}}
$$

where $m_{i}$ is the amount of marker excreted at the $i$ th defecation and $t_{i}$ is the time (h) elapsed since dosage of marker.

\section{Statistical analysis}

Analysis of variance and regression analysis were performed according to conventional methods (Dunn \& Clark, 1974) with consideration of the imbalance in Expt 1 using the GLM-procedure in SAS (SAS, 1982). 
Table 1. Expts 1-3. Mean particle size (MPS), density in water $\left(\mathrm{D}_{\mathrm{w}}\right)$ and chromic oxide $\left(\mathrm{Cr}_{2} \mathrm{O}_{3}\right)$ content of chromium-labelled feeds used*

\begin{tabular}{llcc}
\hline $\begin{array}{l}\text { Cr-labelled } \\
\text { feed }\end{array}$ & $\begin{array}{c}\text { MPS } \\
(\mathrm{mm})\end{array}$ & $\begin{array}{c}D_{w} \\
(\mathrm{~g} / \mathrm{ml})\end{array}$ & $\begin{array}{c}\mathrm{Cr}_{2} \mathrm{O}_{3} \\
(\mathrm{mg} / \mathrm{g})\end{array}$ \\
\hline Cr-H & - & $1 \cdot 23$ & 57 \\
Cr-Bh & $1 \cdot 88$ & $1 \cdot 12$ & 111 \\
Cr-CP & $1 \cdot 80$ & $1 \cdot 30$ & 5 \\
Cr-RSM & $1 \cdot 06$ & 1.44 & 117 \\
& $1 \cdot 38$ & $1 \cdot 31$ & 85 \\
\hline
\end{tabular}

$\mathrm{Cr}-\mathrm{H}$, Cr-labelled hay; $\mathrm{Cr}-\mathrm{Bh}$, Cr-labelled barley hulls; $\mathrm{Cr}-\mathrm{CP}, \mathrm{Cr}$-labelled crushed peas (Pisum sativum); Cr-RSM, Cr-labelled rapeseed meal; Cr-CSM, Cr-labelled cottonseed meal.

* $\mathrm{Cr}-\mathrm{H}$ was not sieved and was milled to pass a $4.5 \mathrm{~mm}$ screen before determining $D_{w}$.

Table 2. Expts 1 and 2. Mean retention time $(M R T ; h)$ of chromium-labelled feed particles $(\mathrm{Cr})$ and of Li-CoEDTA (Co) in the gastrointestinal tract of sheep*

(Least square estimates with their standard errors)

\begin{tabular}{|c|c|c|c|c|c|c|c|c|c|c|}
\hline \multirow{2}{*}{$\begin{array}{c}\text { Expt. } \\
\text { no. }\end{array}$} & \multirow[b]{2}{*}{ Treatment } & \multirow[b]{2}{*}{$\mathrm{d} \mathbf{f}$} & \multicolumn{4}{|c|}{$\mathrm{Cr}$} & \multicolumn{4}{|c|}{ Co } \\
\hline & & & $\mathrm{MRT}_{\mathrm{B}}$ & SEM & $\mathrm{MRT}_{\mathrm{T}}$ & SEM & $\mathrm{MRT}_{\mathrm{B}}$ & SEM & $\mathrm{MRT}_{\mathrm{T}}$ & SEM \\
\hline 1 & $\mathrm{Cr}-\mathrm{H}$ & 4 & $53 \cdot 5$ & $4 \cdot 22$ & 53.9 & $3 \cdot 32$ & _- & - & - & $\ldots$ \\
\hline 1 & $\mathrm{Cr}-\mathrm{Bh}$ & 3 & $52 \cdot 3$ & $4 \cdot 87$ & $54 \cdot 4$ & $3 \cdot 83$ & - & - & - & - \\
\hline 1 & $\mathrm{Cr}-\mathrm{CP}$ & 4 & $44 \cdot 3$ & $4 \cdot 22$ & 45.6 & $3 \cdot 32$ & - & - & - & - \\
\hline 1 & Cr-RSM & 3 & 37.0 & $4 \cdot 87$ & $38 \cdot 6$ & $3 \cdot 83$ & - & - & - & - \\
\hline 2 & Cr-RSM & 16 & 40.7 & 2.40 & 38.8 & 1.37 & $35 \cdot 0$ & 0.62 & $35 \cdot 1$ & 0.35 \\
\hline
\end{tabular}

$\mathrm{Cr}-\mathrm{H}, \mathrm{Cr}$-labelled hay; $\mathrm{Cr}-\mathrm{Bh}$, Cr-labelled barley hulls; $\mathrm{Cr}-\mathrm{CP}, \mathrm{Cr}$-labelled crushed peas (Pisum sativum); Cr-RSM, Cr-labelled rapeseed meal.

* $\mathrm{MRT}_{\mathrm{B}}$ calculated according to Blaxter et al. (1956); $\mathrm{MRT}_{\mathrm{T}}$ calculated according to Thielmans et al. (1978).

\section{RESULTS}

Values for MPS, $D_{w}$ and the concentration of $\mathrm{C}_{2} \mathrm{O}_{3}$ in the feeds used are given in Table 1 . The pretreatment of barley and crushed peas (with amylase followed by detergent and detergent respectively) before labelling markedly changed both the appearance and the particle size compared with the unlabelled feeds. Consequently both $\mathrm{Cr}-\mathrm{Bh}$ and $\mathrm{Cr}-\mathrm{CP}$ consisted entirely of hulls left after the pretreatment of the unlabelled feeds.

\section{Expt 1}

Values for MRT of $\mathrm{Cr}-\mathrm{H}$ and $\mathrm{Cr}-\mathrm{Bh}$ in the GI tract were much longer $(P<0 \cdot 10)$ than those of $\mathrm{Cr}-\mathrm{CP}$ and $\mathrm{Cr}-\mathrm{RSM}$ (Table 2).

Despite considerable variation in faecal output during the day (Fig. 1), estimated MRTs were very similar irrespective of the calculation method used $\left(\mathrm{MRT}_{\mathrm{B}}\right.$ or $\left.\mathrm{MRT}_{\mathrm{T}}\right)$.

$\mathrm{Cr}-\mathrm{CP}$ and $\mathrm{Cr}$-RSM showed markedly faster $(P<0 \cdot 10)$ rumen outflow rates than $\mathrm{Cr}-\mathrm{H}$ and $\mathrm{Cr}-\mathrm{Bh}$ with RRT $(1 / k)$ values of 18.8 and $25 \cdot 2$, and 35.9 and $39 \cdot 7 \mathrm{~h}$ respectively (Table 3).

$$
\text { Expt } 2
$$

The MRT ${ }_{\mathrm{T}}$ and $\mathrm{MRT}_{\mathrm{B}}$ of Cr-RSM $(39 \cdot 1,38 \cdot 6,38 \cdot 5,38 \cdot 9 \mathrm{~h}$ and $41 \cdot 6,40 \cdot 1,40 \cdot 5,40 \cdot 6 \mathrm{~h}$ respectively) and Li-CoEDTA $(36 \cdot 0,35 \cdot 0,34 \cdot 6,34 \cdot 9 \mathrm{~h}$ and $37 \cdot 1,35 \cdot 1,34 \cdot 0,33 \cdot 8 \mathrm{~h}$ respectively) were not significantly affected by adding increasing amounts of unlabelled RSM to the diet. 


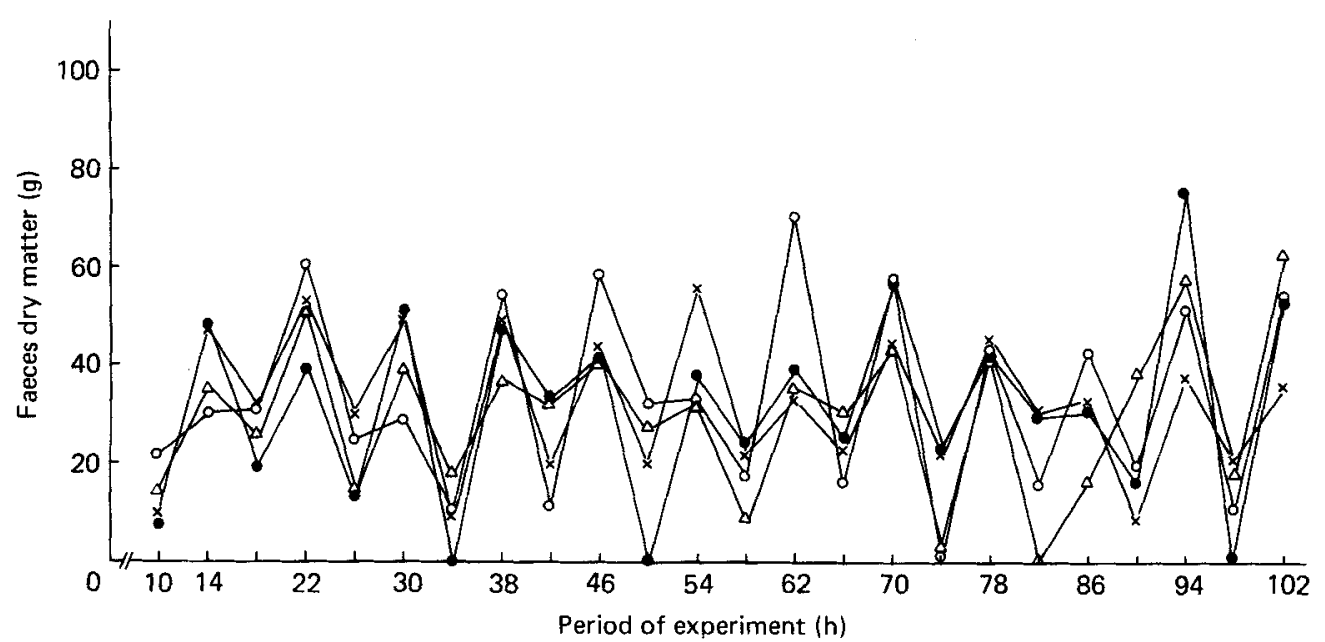

Fig. 1. Expt 1. Faecal output (g) from one sheep during 4-h intervals. (O), Period 1; (O), period 2; $(\triangle)$, period $3 ;(\times)$, period 4 . For details of procedures, see p. 560 .

Table 3. Expts 1-3. Fractional outflow rates $(\mathrm{K})$ from the rumen of sheep of chromium-labelled feed particles $\left(\mathrm{K}_{C r}\right)$ and of Li-CoEDTA $\left(\mathrm{K}_{C o}\right)$

(Least square estimates with their standard errors)

\begin{tabular}{|c|c|c|c|c|c|c|}
\hline $\begin{array}{c}\text { Expt } \\
\text { no. }\end{array}$ & Treatment & df & $K_{\mathrm{Cr}}$ & SEM & $K_{\mathrm{Co}}$ & SEM \\
\hline 1 & $\mathrm{Cr}-\mathrm{H}$ & 4 & 0.0278 & 0.0053 & - & - \\
\hline 1 & $\mathrm{Cr}-\mathrm{Bh}$ & 3 & 0.0252 & 0.0061 & - & - \\
\hline 1 & $\mathrm{Cr}-\mathrm{CP}$ & 4 & 0.0396 & 0.0053 & - & - \\
\hline 1 & Cr-RSM & 3 & 0.0533 & 0.0061 & - & - \\
\hline 2 & Cr-RSM & 16 & 0.0506 & $0 \cdot 0044$ & 0.0463 & 0.0017 \\
\hline 3 & Cr-RSM & 11 & 0.0438 & 0.0032 & 0.0492 & 0.0033 \\
\hline 3 & $\mathrm{Cr}-\mathrm{CSM}$ & 4 & 0.0395 & 0.0049 & 0.0545 & 0.0052 \\
\hline
\end{tabular}

$\mathrm{Cr}-\mathrm{H}, \mathrm{Cr}$-labelled hay; $\mathrm{Cr}-\mathrm{Bh}, \mathrm{Cr}$-labelled barley hulls; $\mathrm{Cr}$-CP, $\mathrm{Cr}$-labelled crushed peas (Pisum sativum); Cr-RSM, Cr-labelled rapeseed meal; Cr-CSM, Cr-labelled cottonseed meal.

Both the MRT $\mathrm{T}_{\mathrm{T}}$ and $\mathrm{MRT}_{\mathrm{B}}$ of water (Li-CoEDTA) and of Cr-RSM were significantly different between animals $(P<0 \cdot 01)$. The range in $\mathrm{MRT}_{\mathrm{T}}$ for $\mathrm{Cr}-\mathrm{RSM}$ was $35 \cdot 1-45 \cdot 4 \mathrm{~h}$ and for Li-CoEDTA $32 \cdot 3-37 \cdot 6 \mathrm{~h}$.

There were no significant effects on rumen outflow rates of Cr-RSM $(0.054,0.045,0.049$, $0.054)$ and Li-CoEDTA $(0.045,0.047,0.048,0.046)$ from adding increasing amounts of unlabelled RSM to the diet (Table 3$)$. However, significantly $(P<0.01)$ different rumen outflow rates of both Cr-RSM $(0.028,0.051 .0 .075,0.049)$ and Li-CoEDTA $(0.033,0.045$, $0 \cdot 061,0.047)$ were found between sheep.

\section{Expt 3}

The values for $\mathrm{MRT}_{\mathrm{T}}$ were $40 \cdot 9$ (SFM 3.32) $\mathrm{h}$ and 38.8 (SEM 3.12) $\mathrm{h}$ for Cr-RSM and $\mathrm{Cr}$-CSM respectively and 34.1 (SEM 1.88) $\mathrm{h}$ and 31.1 (SEM 2.56) $\mathrm{h}$ for Li-CoEDTA in the periods with Cr-RSM and Cr-CSM respectively.

Cr-CSM had a very similar rumen outflow rate compared with $\mathrm{Cr}$-CP in Expt 1 while Cr-RSM was retained longer in the rumen than in Expts 1 and 2 (Table 3). 


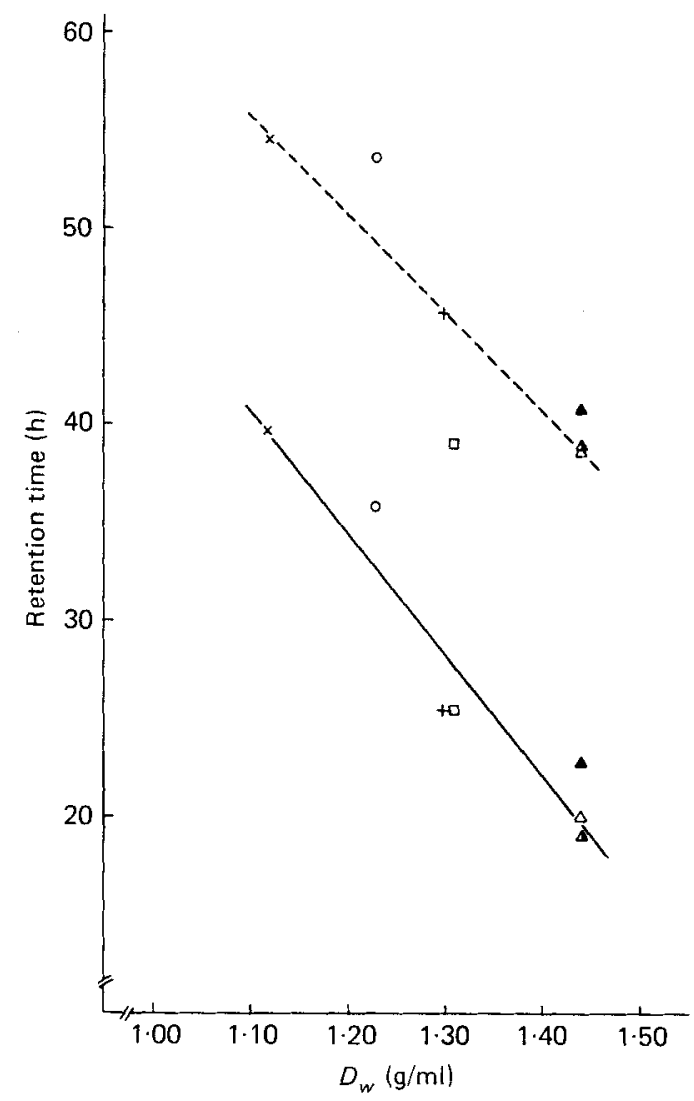

Fig. 2. The relation of mean retention time (MRT) and rumen retention time (RRT) to density $\left(D_{w}\right)$ of chromium-labelled feed particles. (O), Cr-labelled hay; $(+), \mathrm{Cr}$-labelled crushed peas ( Pisum sativum); $(\times)$, Cr-labelled barley hulls; $(\Delta)$, Cr-labelled rapeseed meal $(\mathrm{Cr}-\mathrm{RSM})$ Expt $1 ;(\boldsymbol{\Delta}), \mathrm{Cr}-\mathrm{RSM}$ Expt

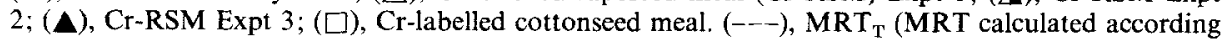
to Thielmans et al. 1978); (- - , RRT.

$$
\begin{gathered}
\text { MRT }_{T}: y=111 \cdot 2-50 \cdot 4 x ; r-0.88, S_{y x} 3.69 \\
\text { RRT: } y=108 \cdot 4-61 \cdot 6 x ; r-0.95, S_{y x} 2 \cdot 70 .
\end{gathered}
$$

No significant period or animal differences were found for $\mathrm{MRT}_{\mathrm{T}}$ or for rumen outflow rates.

\section{DisCUSSION}

\section{Estimation of MRT from faecal spot-samples}

Estimation of MRT using marker concentrations in faecal spot-samples (Thielemans et al. 1978) is based on the assumption of continuous, constant and equal inflow and outflow in the system (Faichney, 1975; Warner, 1981). Errors will arise if there are any substantial deviations from these conditions (Warner, 1981). However, despite the fact that the sheep were fed only three times daily and defecation varied substantially during the day (Fig. 1), the estimated MRT based on total faecal collection and faecal spot-sampling were almost identical. 


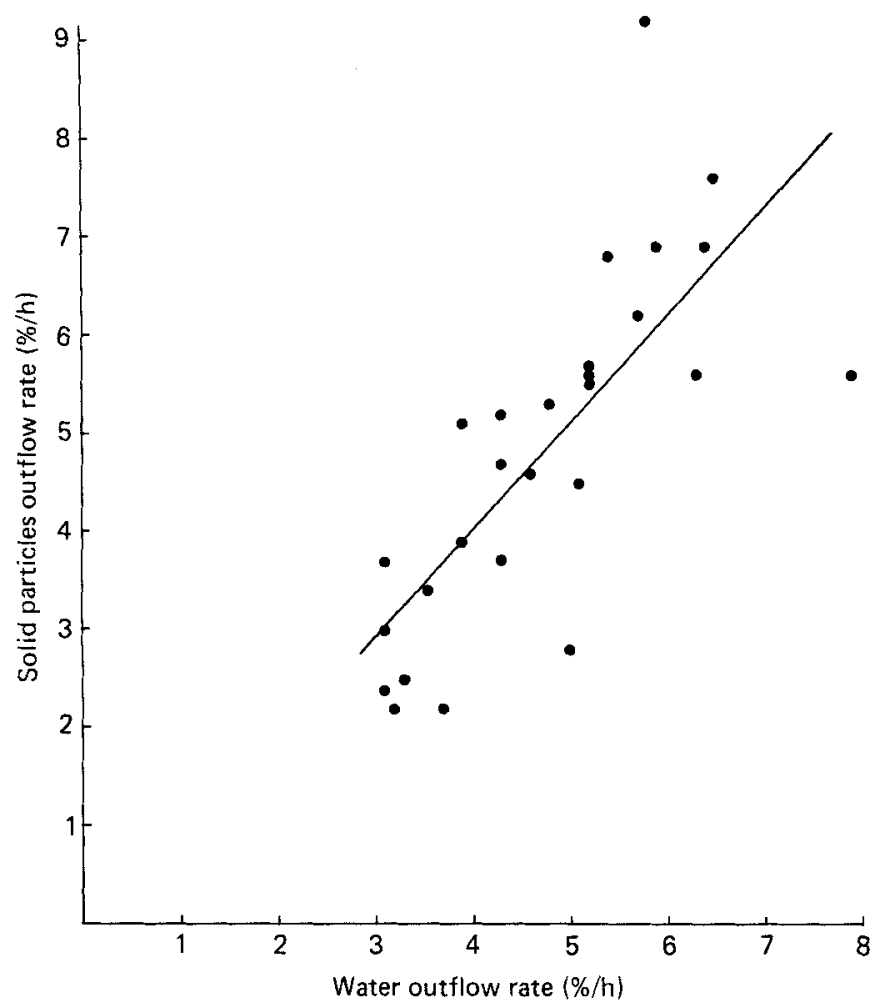

Fig. 3 The relation between the rumen fractional outflow rates $(\% / \mathrm{h})$ of chromium-labelled rapeseed meal (solid particles) and Li-CoEDTA (water) in sheep fed at maintenance.

$$
y=1.09 x-0.38 ; n 27, r 0 \cdot 76, S_{y x} 1 \cdot 2, P<0.001
$$

Feed particle size

The present results indicated that the larger feed particles had a longer total MRT in the GI tract than smaller feed particles. This finding was in agreement with the effect on MRT of reducing feed particle size found by Alwash \& Thomas $(1971,1974)$ and Dafaalla \& Kay (1980) in sheep, by Castle (1956b) in growing goat kids and by Campling \& Freer (1962) in cows. A major part of the differences in MRT between the Cr-treated feeds was due to differences in RRT $(1 / k)$.

The similar MRT and rumen outflow rates of $\mathrm{Cr}-\mathrm{H}$ and $\mathrm{Cr}-\mathrm{Bh}$ were unexpected as they differed a lot in initial particle size. They were, however, in agreement with other studies (Eng et al. 1964; Thomas \& Campling, 1977). This indicated that differences in initial particle size and brittleness of feeds to a large extent can be eliminated due to the effective chewing in sheep (Ulyatt, 1982). The rumen outflow rates of Cr-RSM, Cr-CP and Cr-CSM are comparable with, but often higher than, the values reported for Cr-labelled soya-bean meal and $\mathrm{Cr}$-labelled fish meal at similar feeding levels in diets of long or chopped dried grass (Mansbridge \& Ørskov, 1980; Elimam \& Ørskov, 1982; Elimam, 1983). It is not to be expected that differences in diets fed in the referred experiments would have a significant effect on RRT of small feed particles (Elimam, 1983) in comparison with the diets fed in the present study. Neither would differences in the size of animals in the present study and the studies referred to be expected to have any significant effect on rumen outflow rates (Castle, 1956a,b).

The RRT $(1 / k)$ of large feed particles includes both the rumen outflow rate of small 
Table 4. The relation between solid particle outflow rate $(\mathrm{y}, \% / h)$ and liquid outflow rate $(\mathrm{x}, \% / h)$ in sheep

\begin{tabular}{ll} 
Equation & Reference \\
\hline$y=1.44+0.59 x ; n 6, r 0.94$ & Grovum \& Williams (1973) \\
$y=1 \cdot 12+1.13 x-0.06 x^{2} ; n 11, R 0.95$ & Faichney \& Griffiths (1978) \\
$y=-0.38+1.09 x ; n 27, r 0.76$ & Present study \\
\hline
\end{tabular}

particles and the time needed for mixing and physical breakdown of the feed. It is therefore possible that the rumen outflow rate of $\mathrm{Cr}-\mathrm{H}$ was underestimated due to this (Dixon et al. 1983).

\section{$\mathrm{D}_{\mathrm{w}}$ and specific weight of feed particles}

Widely differing values of $D_{w}$ were found for the Cr-treated feeds tested (Table 1). However, it was found that the the MRT and RRT of Cr-H, Cr-Bh, Cr-CP, Cr-CSM and Cr-RSM were closely related to the density of the particles (Fig. 2).

Campling \& Freer (1962) have shown that the MRT of rubber particles is related to their specific weight. Very little is known about the specific weight of commonly-used feeding stuffs. In contrast to specific weight $D_{w}$ also includes unique properties of the feed, i.e. trapped air within the feed. Therefore it seems likely that differences in $D_{w}$ have a greater biological significance in relation to the passage of feeds from the rumen than differences in their specific weight. This was supported by the passage of $\mathrm{Cr}-\mathrm{H}$. The $D_{w}$ of coarsly-milled $(4.5 \mathrm{~mm}) \mathrm{Cr}-\mathrm{H}$ was $1.23 \mathrm{~g} / \mathrm{ml}$ while finely-milled $(1.0 \mathrm{~mm}) \mathrm{Cr}-\mathrm{H}$ had a $D_{w}$ of $1.37 \mathrm{~g} / \mathrm{ml}$. The latter value is in between the $D_{w}$ of Cr-CSM and that of Cr-RSM. A decrease in MRT with increasing comminution (Blaxter et al. 1956; Alwash \& Thomas, 1971, 1974) could therefore be explained in terms of $D_{w}$ changes and is not necessarily due to the reduction in particle size per se. The observation that the dimensions of the reticulo-omasal orifice when open is much greater than the size of particles found post-rumen (McBride et al. 1983) gives further support for these suggestions.

\section{Small particle and water outflow rates}

Although not entirely consistent, the total MRT and RRT of water tended to be shorter than those of small feed particles. This is in agreement with the results of Ellis \& Huston (1968), Grovum \& Williams (1973) and Faichney \& Griffiths (1978). A wide range of rumen outflow rates of both water and small feed particles were found between animals in the present study. Similar observations have been made in sheep (Faichney \& Griffiths, 1978; Elimam, 1983), in goats (Castle, 1956 b) and in cows (Hartnell \& Satter, 1979). It was also observed that in each animal used the outflow rates of water and small particles (Cr-RSM) from the rumen were closely related (Fig. 3). Recalculation of the values from Grovum \& Williams (1973; Expt 5) and Faichney \& Griffiths (1978; excluding the data for large particles) reveals a similar trend (Table 4). Grovum \& Williams (1973) fed a diet of lucerne (Medicago sativa) chaff while Faichney \& Griffiths (1978) fed a pelletted all-concentrate diet. In both these papers Cr-EDTA was used as a liquid-phase marker and rare earth metals as solid-phase markers; the latter is known to adhere strongly to feed particles (Ellis \& Huston, 1968). The increase in particle outflow rate with increasing water outflow rate was close to unity in the present experiment and in that of Faichney \& Griffiths (1978) but gave a quadratic response $(P<0.05)$ in the values from Faichney \& Griffiths (1978). A markedly lower increase in particle relative to water outflow rates was found in the values of Grovum 
\& Williams (1973). However, the diets used in the present study and in the previously described experiments were entirely different both with respect to composition and initial particle size. If we accept that the liquid and particulate phases do not behave independently in the caecum-proximal colon of sheep (Faichney \& Boston, 1983), this indicates that the rumen outflow rates of small feed particles are closely related to changes in water outflow rates but also that these effects are different in different feeding situations. One possible explanation could be varying degrees of entrapment of small particles in rumen digesta (Welch, 1982) in concentrate and roughage diets.

\section{REFERENCES}

Agricultural Research Council, (1980). The Nutrient Requirements of Ruminant Livestock. Farnham Royal: Commonwealth Agricultural Bureaux.

Alwash, A. H. \& Thomas, P. C. (1971). Journal of the Science of Food and Agriculture 22, $611-615$.

Alwash, A. H. \& Thomas, P. C. (1974). Journal of the Science of Food and Agriculture 25, 139-147.

Balch, C. C. (1950). British Journal of Nutrition 4, 361-388.

Blaxter, K. L., Graham, N. McC. \& Wainman, F. W. (1956). British Journal of Nutrition 10, 69-91.

Campling, R. C. \& Freer, M. (1962). British Journal of Nutrition 16, 507-518.

Castle, E. J. (1956a). British Journal of Nutrition 10, 15-23.

Castle, E. J. (1956b). British Journal of Nutrition 10, 115-125.

Dafaalla, B. F. M. \& Kay, R. N. B. (1980). Proceedings of the Nutrition Society 39, 71A.

Dixon, R. M., Kennelly, J. J. \& Milligan, L. P. (1983). British Journal of Nutrition 49, 463-473.

Dunn, O. J. \& Clark, V. A. (1974). Applied Statistics. Analysis of Variance and Regression. New York: John Wiley \& Sons.

Elimam, M. E. (1983). Measurement of and factors affecting the outflow of dietary proteins from the rumen of sheep and lactating dairy cows. PhD Thesis, University of Aberdeen.

Elimam, M. E. \& Ørskov, E. R. (1981). Animal Production 32, 386.

Elimam, M. E. \& Ørskov, E. R. (1982). Proceedings of the Nutrition Society 41, 29 A.

Ellis, W. C. \& Huston, J. E. (1968). Journal of Nutrition 95, 67-78.

Eng, K. S. Jr, Riewe, M. E., Craig, J. H. Jr \& Smith, J. C. (1964). Journal of Animal Science 23, $1129-1132$.

Faichney, G. J. (1975). In Digestion and Metabolism in Ruminants, pp. 277-291 [I. W. McDonald and A. C. I. Warner, editors]. Armidale, New England: University of New England Publishing Unit.

Faichney, G. J. \& Boston, R. C. (1983). Journal of Agricultural Science, Cambridge 101, 575-581.

Faichney, G. J. \& Griffiths, D. A. (1978). British Journal of Nutrition 40, 71-82.

Grovum, W. L. \& Williams, V. J. (1973). British Journal of Nutrition 30, 313-329.

Hartnell, G. F. \& Satter, L. D. (1979). Journal of Animal Science 48 381-392.

Institut National de la Recherche Agronomique (1978). Alimentation des Ruminants. Versailles, France: INRA. McBride, B. W., Milligan, L. P. \& Turner, B. V. (1983). Journal of Agricultural Science, Cambridge 101, 749-750. Mansbridge, R. J. \& Ørskov, E. R. (1980). Animal Production 30, 486-487.

Ørskov, E. R. \& McDonald, I. (1979). Journal of Agricultural Science, Cambridge 92, 499-503.

Robertson, J. B. \& Van Soest, P. J. (1977). Paper presented at American Society of Animal Sciences, University of Wisconsin, July 23-27.

SAS (1982). SAS User's Guide: Statistics. Cary, NC: SAS Institute Inc.

Shipley, A. R. \& Clark, R. E. (1972). Tracer Methods for in vivo Kinetics. Theory and Application. London and New York: Academic Press.

Stevenson, A. E. \& de Langen, H. (1960). New Zealand Journal of Agricultural Research 3, 314-319.

Thielemans, M. R., Francois, E., Bodart, C. \& Thewis, A. (1978). Annales of Biological Animal Biochemistry and Biophysics 18, 237-247.

Thomas, S. \& Campling, R. C. (1977). Journal of British Grassland Society 32, 33-41.

Udén, P., Colucci. P. E. \& Van Soest, P. J. (1980). Journal of the Science of Food and Agriculture 31, $625-632$.

Udén, P. \& Van Soest, P. J. (1982). Animal Feed Science and Technology 7, 35-44.

Ulyatt, M. J. (1982). In Fibre in Human and Animal Nutrition, The Royal Society of New Zealand Bulletin no. 20, pp. 103-107 [G. Wallace and L. Bell, editors]. Wellington: Royal Society of New Zealand.

Van Soest, P. J. \& Wine, R. H. (1967). Journal of the Association of Official Analytical Chemists 50, 50-55.

Waldo, D. R., Smith, L. W. \& Cox, E. L. (1973). Journal of Dairy Science 55, 125-129.

Warner, A. C. I. (1981). Nutrition Abstracts and Reviews Ser. B 51, 789-820.

Welch, J. G. (1982). Journal of Animal Science 54, 885-894. 